\title{
The Evolution of Price Discrimination in Transportation and its Implications for the Internet
}

\author{
ANDREW ODLYZKO * \\ University of Minnesota University of Minnesota
}

\begin{abstract}
A wide-ranging discussion of the evolution of pricing in early transportation industries, such as lighthouses, canals, and turnpikes, is presented. It shows that price discrimination was an important factor in the development of those industries, and tended to intensify with time. In order to make differential tariffs effective, service providers had the right of detailed inspection of the cargo. These historical precedents help explain the drive by large sectors of the telecommunications industry to gain greater control over what is transmitted over the Internet. The implications for the evolution of the Internet are briefly explored.
\end{abstract}

\section{Introduction}

With telecommunications in a slump, the search is on for ways to re-invigorate this key industry. The main problems are clearly economic much more than technological, and many of the proposed remedies would lead to new architectures for the Internet that would provide for greater control by carriers. The fundamental question in all the discussions about open access, unbundling, line sharing, and related policies is whether carriers should be able to restrict voice over Internet (VoIP) services or control what movies customers receive over their broadband connections. The objective would be to impose differential charging, taking advantage of the wide disparity in willingness to pay for different types of communications services shown in Table $1{ }^{1}$

\footnotetext{
* Mailing address: Digital Technology Center, University of Minnesota, 499 Walter Library, 117 Pleasant St. SE, Minneapolis, MN 55455, United States. E-mail address: odlyzko@umn.edu Sasha Nichols-Geerdes provided extensive and valuable research assistance in locating historical sources. Jouko Tossavainen helped with pointers to information about the Sound Tolls. Ted Stout provided helpful perspectives on the transportation industry, and Sam Paltridge references to telecom liberalization analyses. Ross Anderson, Dan Bogart, Bob Briscoe, Liudvikas Bukys, Dave Burstein, Steve Crandall, Daniel Davis, Rolf Engstrand, Bob Frankston, Jim Gray, Tom Hazlett, Chris Hogendorn, Tim Janik, Ihor Lys, Paul Odlyzko, Andy Oram, Hal Purdy, Jere Retzer, Nate Taylor, Adam Thierer, and Philip Webre helped with comments on an earlier draft. ${ }^{1}$ These are estimates of what U.S. residential users pay per megabyte of traffic from various sources. The methodology used in constructing the table is only approximate (for example, the cable TV rate is computed
} 


\begin{tabular}{|l|l|l|}
\hline Service & $\begin{array}{l}\text { Typical revenue monthly } \\
\text { bill }\end{array}$ & Revenue per MB \\
\hline Cable & $\$ 40$ & $\$ 0.00012$ \\
\hline broadband Internet & $\$ 50$ & $\$ 0.025$ \\
\hline Phone & $\$ 70$ & $\$ 0.08$ \\
\hline dial Internet & $\$ 20$ & $\$ .33$ \\
\hline cell phone & $\$ 50$ & $\$ 3.50$ \\
\hline SMS & & $\$ 3000$ \\
\hline
\end{tabular}

Table 1. Value of bits: Cost per megabyte of various services.

The advantages of such practices are well known to economists as well as business leaders, as shown by an email of August 17, 1997 from Warren Buffett, the famous investor and head of Berkshire Hathaway, to Jeff Raikes of Microsoft (made public through a lawsuit, and quoted partially in Wilke and Clark, 2004)):

[Alexander Graham] Bell should have anticipated Bill [Gates] and let someone else put in the phone infrastructure while he collected by the minute and distance (and even importance of the call if he could have figured a wait [sic] to monitor it) in perpetuity.

Such differential charging according to values of individual transactions is foreign to today's voice telephone business (although it had been attempted in the past). ${ }^{2}$ However, other price discrimination practices are rife, such as high charges for roaming in mobile telephony, or charging more for a basic wired connection for a business customer than for a residential one.

The Internet owes its success largely to the end-to-end principle, which concentrates functionality at the edges, and relegates most of the network to a "dumb pipe". This structure makes it difficult for service providers to engage in differential pricing. The concern is that without price discrimination, they will not have the incentive to build out and maintain the network. As broadband connections spread in both wireline and wireless sectors, the Internet is taking over other services, giving rise to concerns about viability of the entire telecommunications system.

Historical precedents in telecommunications argue for continuation of the trend towards simplicity, as is shown in Odlyzko (2001b). However, the picture is completely different if we look at another network industry, namely transportation. There differential pricing has been the norm, as is shown by Table 2, which presents some of the tolls charged by the Beverley Beck Navigation in $18^{\text {th }}$ century England. ${ }^{3}$

by assuming average daily viewing time of four hours, with a signal carrying $6 \mathrm{Mb} / \mathrm{s}$, and the SMS rate comes from assuming an average of 33 bytes per message, at 10 cents for each message), but the wide range of prices is striking and persists even if we modify the assumptions underlying the calculations within reasonable bounds.

${ }^{2}$ The postal system built and ran the telephone system in the U.K.. An interesting incident is related on p.102 in Marvin (1990):

In Britain in 1889, postal officials reprimanded a Leicester subscriber for using his phone to notify the fire brigade of a nearby conflagration. The fire was not on his premises, and his contract directed him to confine his telephone "to his own business and private affairs." The Leicester Town Council, Chamber of Commerce, and Trade Protection Society all appealed to the postmastergeneral, who ruled that the use of the telephone to convey intelligence of fires and riots would be permitted thenceforth.

${ }^{3}$ The full toll schedules were quite long, and can be found in Priestley (1967). See also footnote 5. The "before 1744" column shows the charges according to the 1726 charter, the "after 1744" column those after a 


\begin{tabular}{|l|l|l|}
\hline Cargo & Before 1744 & After 1744 \\
\hline Sand & 2 & 2 \\
\hline timber, stone, salt & 4 & 6 \\
\hline Iron and lead & 4 & 12 \\
\hline
\end{tabular}

Table 2. Selected $18^{\text {th }}$ century tolls on the Beverley Beck navigation (in pence per ton).

This paper sketches the historical development of pricing in some early transportation industries. The general trend there has been towards increasing price discrimination and more complicated pricing (although with many noteworthy reversals). Charging according to the nature of the goods being transported has been and continues to be the norm. Since the incentives to price discriminate are increasing, and the ability to do so is also growing, it is conceivable that telecommunications might break with its historical record and follow the example of transportation. It is therefore of interest to examine the evolution of pricing and quality differentiation in transportation.

Some brief discussion is presented at the end of how applicable the transportation precedents might be to telecommunications and the Internet. The general conclusion is that the substantial differences between the Internet and transportation call for caution in invoking the differential pricing principles of early transportation systems, especially since modern transport has changed substantially.

\section{Lighthouse fees and other maritime tolls}

English lighthouse fees present an interesting case study. Contrary to a myth inspired by Coase (1974), they were set by government charters, not by commercial negotiations. (See the Appendix for more details.) Lighthouse owners could not modify them unilaterally to maximize their profits. Still, there was evolution in charging. What we observe is that as time went on, schedules of fees tended to become more sophisticated. The first recorded grant, from 1261, provided for a fee of two pence for each ship Trethewey (2004). By the $16^{\text {th }}$ century, we see payment schedules of 6 pence for a two-masted ship, 4 pence for a one-masted ship, and 2 pence for other vessels. In the $17^{\text {th }}$ century, charging according to the cargo-carrying capacity of the ship becomes dominant. By the end of the $19^{\text {th }}$ century, we find the system described by Coase (1974), in which ships paid a fee (depending on their cargo-carrying capacity) for each entry into or exit from a harbor up to a certain number, and nothing more for the remainder of the year. (Such non-linear tariffs do have significant advantages in collecting payments for services with low or zero marginal cost, as was argued in Coase,1946). We do encounter them in everyday life, for example in restaurants that offer free refills of coffee or other drinks.)

British lighthouse duties show growth in complexity, but these levies did not require knowledge of the nature of the cargo, if any. Moreover, government acquisition of private

revised charter was granted in 1744 . These tolls were entirely separate from charges for carriage, which were paid to boat owners. The navigation project did not have any costs that depended on the nature of the cargo. (The project's costs were primarily the costs of dredging the channel. To the extent that boats being towed through the channel created waves that damaged the banks, or the towpaths got worn, the associated expenses were the same whether the boat carried salt or iron or nothing at all.) 
lighthouses, authorized by Parliament in 1836, was stimulated by a desire to lower the level of fees and also to make them more uniform. Many of the complaints were about the complexity and the associated non-monetary costs of the old system. (This was a time of the great movement to liberalize trade, which reduced tariffs and other impediments. The famous Rhine tolls were abolished in that era as well.)

In general, lighthouse dues appear to have been only a small part of the total cost of shipping. Coase (1974) cites figures for 1971-1972 that indicate that revenues of the General Lighthouse Fund were then on the order of two thirds of one percent of the cost of running ships trading with the U.K., and thus a tiny fraction of the value of the goods shipped. Some rough estimates show lighthouse fees were also low compared to cargo value or transportation costs in earlier times. For example, in the early 1830 s, the estimate for the total revenues of all lighthouses (before they were nationalized and fees lowered) was at most a quarter of a million pounds sterling Prouty (1957), as compared to total value of exports and imports alone (and thus excluding the considerable domestic sea transport) of over three hundred times as much.

It is particularly noteworthy that lighthouse charges grew in complexity even though they were low compared to other costs involved in shipping. As was remarked by Coase (1974), it is hard to imagine that many decisions whether to make a voyage, or from which harbor to make one, depended on the level of lighthouse fees. It would be nice to investigate this evolution in sophistication of charging schemes, to find out what kinds of arguments were used for and against it. It is likely that it was concern about fairness (and the related issues of shipper complaints and evasion) that dominated, as has been true historically, and is likely to be increasingly prominent in the future (Odlyzko, 2003d). The pricing of goods and services of low marginal cost is often a matter of moral philosophy. It is not uncommon for people with no direct interest in the subject to argue vehemently that flat rate pricing is morally wrong because it forces light users to subsidize heavy ones, say.

British lighthouses provide an interesting example of pricing that was moderately complicated and intrusive. Other countries had other policies. The U.S., for example, has from the beginning had lighthouse service provided by the Coast Guard, paid for out of general federal government funds.

A different and very interesting example is that of the Danish Sound Tolls. Their records have been studied extensively, since they are unusually complete and provide an unparalleled view of the economy of Northern Europe. Collected in Helsingor (the Elsinore of Shakespeare's Hamlet), the Sound Tolls evolved, primarily in the 1548-1567 period, out of "beaconage", "a minor ship-toll in two classes according to the sizes of the ships" (Christensen, 1941, p.301) for providing navigation beacons. In 1548, a "lightage" levy of $1 \%$ of value of cargo was imposed on goods shipped by merchants of some countries, and in 1567 "lastage", a duty based on volume measurement of ships, was introduced. The structure and the level of the Sound Tolls kept changing, and were very complicated, since international treaties meant charges levied on cargo varied depending on the nationality of the cargo owner (not that of the ship carrying the cargo). For more details, see the books Christensen (1941) and Maczak (1972). The interesting point is that as the Sound Tolls' bite increased, so did their sophistication. Initially lastage was projected by Danish financial leaders as a fairly simple levy, "based on cargo capacity, with ships in ballast paying half." However, customs officials persuaded the king to modify it, so that "from the very beginning [it was] collected not according to number of lasts, but to a specially elaborated tariff, in which the rates were not only adapted 
according to the units of weight and measure used, but also graduated according to the kind and value of the merchandise" (Christensen, 1941, pp.299-302). ${ }^{4}$

Compared to British lighthouse duties, the Sound Tolls were much higher, and more intrusive, since they required detailed information about the nature of the cargo, both its value and its ownership. Complaints and abuses were frequent, and led to simplification. First a treaty of 1841 led to relatively uniform ad valorem 1\% toll, and then in 1857 the Sound Tolls were abolished entirely. The abolition was the result of several countries, including the U.K. and the U.S., paying a lump sum to the Danish government. The motivation was to free international trade of what was perceived as a costly encumbrance. The Select Committee on Sound Dues of the (British) House of Commons in 1856 complained of the level of dues, "but mainly [of] the manner in which they [were] collected".

\section{Canals and river navigation projects}

During the Ming dynasty in China ( $14^{\text {th }}$ to $17^{\text {th }}$ centuries) charges for commercial shipping on the Grand Canal were a combination of simple charges based on cargo-carrying capacity of a boat, a charge based on the value of the cargo (initially nominally $1 / 30$ of the market value, with some exceptions), and a few other fees (Huang, 1964). The ad valorem charge was part of the general excise tax system used in China at that time, and in many cases apparently "was omitted, after the tonnage was paid" (Huang, 1964, p.176). In general, though, the excise tax was very elaborate, and at the end of the Ming dynasty had listings for more than 1,900 articles. There were various irregular exactions by officials, and "[t]hroughout the Ming dynasty few complaints about business taxes were directed to the rate, most of them were about abuses and duplicated collections" (Huang, 1964, p.184). The key point for us is that there was extensive charging according to the value of the cargo.

In England (as well as in many other countries), canals were preceded by river navigation projects. Government was active in two main areas. One was in controlling the exactions of mill and weir owners, who often charged what were regarded as extortionate fees (Thacker, 1968 and Willan. 1964). The other, which developed more slowly, with the most intensive growth starting in the early $17^{\text {th }}$ century (Willan, 1964), was in authorizing navigation improvement projects. These were usually based on permissions given to private individuals, municipalities, or monasteries to dredge rivers, or straighten their courses, or construct locks, in return for the right to levy fees on boats. There appeared to be substantial variation in charging schemes, with a general tendency towards schemes that are more elaborate and correspond more with the value of service. The very first Act of Parliament in this area was for improvements on the river Lea in 1424. A subsequent Act of around 1430 provided for a toll of fourpence for each "laden ship or boat leaving or entering the river" (Clifford, 1885, p.469). Later, on the Thames (which for many centuries was a vital commercial artery for England), tolls for using locks were generally per ton of

\footnotetext{
${ }^{4}$ Modern economic concepts and models were not available back in the 16th century, but decision makers often did come up with ingenious schemes. For example, the ad valorem levy was on the declared purchase price of the cargo, which produced obvious incentives to falsify documents to show low value. To deal with such abuses, the Danish crown had the right to purchase goods at the declared value (Maczak, 1972), diminishing the incentive to cheat.
} 
capacity of boat, usually for round trip, sometimes per passage, and sometimes if a boat returned empty, half the toll was rebated (Thacker, 1968, p.162). A lease from 1638 provided for flat rates for each passage up or down, but with different rates for flat bottom boats and barges (Thacker, 1968, pp.75-76). The nature of the cargo, and even the volume of freight carried, did not play a role. With time, though, we begin to see increased reliance on charging according to amount of goods shipped, usually by weight.

The evolution of tolls is nicely illustrated by the Beverley Beck navigation project, described in Duckham (1972) and in much more detail in MacMahon (1971). This was operated by a municipal non-profit organization, although the revenues were sometimes used for purposes such as street repairs, and not just for improvement of water transport. The first Act of Parliament, enacted in 1727, had fairly simple tolls, although there was variation even there, with sand charged 2 pence per ton, and salt, iron, lead, timber, and stone 4 pence per ton (Priestley, 1967). ${ }^{5}$ This was insufficient to cover the costs, and in 1744 the navigation corporation petitioned Parliament, asking for a more appropriate toll schedule. The basic point they made was that "[p]art of the trouble lay in the tolls not being proportionate to the value of the goods transported" (Duckham, 1972, p.9 and MacMahon, 1971). Parliament responded by granting a new charter, with a more elaborate and generally much higher toll structure. ${ }^{6}$ Charges for sand remained at 2 pence per ton, those of timber, stone, and salt were raised from 4 to 6 pence per ton, and those for iron and lead raised from 4 to 12 pence per ton, as shown in Table 2. The change in tolls, along with other changes in policy, and a generally growing level of economic activity, did bring a measure of success to the Beverley Beck project. The interesting point here is that this was a non-profit enterprise that operated right on the verge of sustainability, and a rebalancing of tolls appeared to make a measurably positive impact. But the case is not iron clad, since the general increase in tolls was likely much more important.

Canals were the next step up from river navigation projects in complexity, cost, and efficiency. An interesting example is presented by the Dutch trekvaarten system of canals and canal boats constructed for passenger transportation in the middle of the $17^{\text {th }}$ century (de Vries, 1981). It provided the Netherlands with a communication system that for over a century was superior to that of any other country. Various pieces of the system were built by agreement between pairs of cities. Hence, as has traditionally been common with government systems, there was simple and inflexible pricing, with two classes of service, and fees that did not vary much over a century and a half. With time, though, incentives to price discriminate began to make their mark, and provisions were made for cut-rate or even free travel by the poor. Overall, though, there was relatively little price discrimination, and pricing was rigidly controlled by city governments. The general rigidity of the trekvaarten system imposed by government construction and control did lead to some missed opportunities to make this once-novel system more competitive with emerging alternatives (see de Vries, 1981 for a discussion).

The Dutch canals were built in a very favorable terrain of a flat country, with easy to handle soils and plenty of water. A far more challenging project was the French Canal du Midi, also called the Canal du Languedoc, constructed at the end of the $17^{\text {th }}$ century (during the reign of Louis XIV) to provide an inland link within France between the

\footnotetext{
${ }^{5}$ The actual list was considerably longer, and included items such as 4 pence for each 32 firkins of butter. All references to pence in this paper are to the old British pence, with 240 of them to the pound.

${ }^{6}$ It appears from the remarks in Priestley (1967) that a restriction was imposed, forbidding the use of these toll revenues for purposes other than improvements of navigation.
} 
Atlantic ocean and the Mediterranean. It was a stunning technological achievement. It was also a financial dud for its government and private investors. Still, tolls on this canal were from the very beginning dependent on the nature of the cargo, with an elaborate schedule of fees (Maistre, 1968, pp.193-197).

Although the technology of the Canal du Midi was widely known and admired, its poor financial results appear to have deterred attempts to imitate it. The modern canal era can be said to start with the Duke of Bridgewater's Canal in England. Originally it was just a means of connecting the Duke's coal mines to Manchester. The parliamentary charter (which enabled him to take over private property, with appropriate compensation) obliged the Duke to carry cargo to Manchester at a maximum charge of 30 pence a ton, and to sell his own coal in Manchester for no more than 80 pence a ton, about half the price that had prevailed before, Kirkaldy and Evans (1915) and Priestley (1967). Parliament was determined to obtain substantial benefits for the public from the grant of government powers to the Duke.

The initial canal built by the Duke of Bridgewater was soon afterwards extended to a canal providing a general freight connection between Liverpool and Manchester. This was then followed by other canals. Interestingly enough, in the deliberations leading to the grants of charters for some of these projects, owners of river navigation projects that were likely to be adversely affected by the competition sometimes argued that even if a canal charter were to be granted, it should allow only for tolls based on weight of cargo, independent of the nature of the cargo (Brindley, 1766, part 2, p.101) and Phillips, 1792, pp.194-200):

The owners and trustees of the old navigations beg leave to submit, "that the tonnage, collected by the company of proprietors, ought to be equal, through the whole canal, for every species of goods; with some particular exceptions."

Note that even these petitioners could not deny completely the logic of differential pricing, and felt compelled to allow for "some particular exceptions". At an even more basic level, charging by the tons of cargo is already a nod in the direction of price discrimination, since costs of operating a canal depend only on the damage done by a boat, and that has little relation to the cargo that is carried. The power of price discrimination was understood very well in those days, and was greatly feared. There was a frequently expressed and strong preference for simple rates. As an example, consider the following passage from Phillips (1792, pp.vii-viii):

When the carriages which pass over a highway or a bridge, and the lighters and barges which are used upon a navigable canal, pay toll in proportion to their weight or their tonnage, they pay for the maintaining [sic] those public works in proportion to the wear and tear which they occasion. A more equitable way of maintaining such works cannot be found; for the tax or toll, though advanced by the carrier, is finally paid by the consumer, to whom it is charged in the price of his goods.

But the incentives to price discriminate were powerful enough to overcome such moral concerns.

The great financial success of the Duke of Bridgewater's Canal led to widespread attempts to emulate it. In the early $1790 \mathrm{~s}$, there was a canal mania, with a burst of construction that was never to be replicated in Britain. (The U.S. had its canal mania some decades later, following on the great success of the Erie Canal.) The charters of those 
canals show a general trend towards greater price discrimination. ${ }^{7}$ As described by one historian, "whereas the Trent \& Mersey in 1766 had been granted tolls of [1.5 pence per ton per mile] on everything, the Grand Junction in 1793 was given [1 pence] on merchandise, $[0.75$ pence $]$ on coal, $[0.5$ pence $]$ on building material, and [0.25 pence] on lime and limestone" (Hadfield, 1968, p.78). There was also almost a universal requirement in charters that forced canals to allow for free carriage of manure for adjacent fields as well as of stone for road repairs. Unfortunately there do not appear to be any studies of the reasons for the wide variation in toll schedules. Were they selected with careful thought on their economic impact, or just in response to political pressure from local interests?

Similar toll schedules depending on cargo were also common in the United States. As an example, when parts of the still incomplete Erie Canal were opened in 1820, there was a long list of tolls, concluding with "All articles not enumerated, one cent, per ton, per mile" (Whitford, 1906, Chapter 2). The enumerated articles (among those that were measured by the ton) were charged tolls ranging from salt and gypsum at 0.5 cents per ton per mile, to 1 cent for flour, to 2 cents for merchandise, and nothing for fuel to be used in the manufacture of salt (so that it was necessary not only to know the nature of the cargo, but its ultimate use).

It is worth noting that canal tolls were a very substantial part of the cost of canal transport. There do not appear to be any systematic studies on this subject, but there are various snippets of information that suggest tolls often were more than half the total cost. ${ }^{9}$ Thus, unlike for the telecommunications case to be discussed in later, there were high costs (to users, representing primarily the high capital cost of construction) in the core of the network.

Today, canal and maritime tolls still vary, and often depend on the nature of cargo. The Erie Canal is open again, and is used almost exclusively for recreational purposes. The tolls for private boats depend just on the length of the boat. Fee schedules for commercial vessels are complicated, including flat annual fees. On the Panama Canal, tolls depend on the tonnage measurements using that canal's own rules, with charges higher when carrying passengers or cargo, but not depending on the nature of the cargo. On the St. Lawrence Seaway, tolls include charges depending on tonnage measurements, lock fees, as well as levies varying with the nature of the cargo. For example, in 2002, Welland Canal charges varied from Canadian $\$ 0.6072$ per ton of coal or containerized cargo, to $\$ 0.6956$ for steel slab, and $\$ 0.9717$ for general cargo. Curiously enough, on the Montreal/Lake Ontario section of the Seaway, charges were lowest for coal, at $\$ 0.541$ per ton, considerably higher for containerized cargo, at $\$ 0.9164$ per ton, and over four times as high for general cargo, at $\$ 2.2081$ per ton.

Canals in England were traditionally strongly restricted to offering their superior water transportation facilities to carriers, and generally could not act as carriers themselves. This prohibition was only eliminated in 1845, in order to strengthen canal operators in their

\footnotetext{
${ }^{7}$ There is an excellent summary source on canal charters in the compilation Priestley (1967). It is hard to do careful quantitative studies with that data, though, until one obtains more information about expected traffic on the various canals and the political factors that were involved in the parliamentary decisions.

${ }^{8}$ Some of the correspondence presented in Willan (1965, pp.53, 54, and 59), involving negotiations between two towns prior to going to Parliament for approval of a river navigation act in the 1720 s suggests that political considerations played a major role.

${ }^{9}$ For example, p.128 of Willan (1964) mentions a certain canal, where transport of a chaldron of coal was expected to cost 30 pence for tolls and 18 pence in fees to carriers for use of the barge.
} 
competition with railways. ${ }^{10}$ Thus this was an early example of the kind of structural separation that is occasionally being proposed for telecommunications, with a basic network operator and other operators providing services on top of that operator's facilities. However, canals did search for other ways than those specified by their charters to increase their profits, and to price discriminate more effectively than allowed by their charters' toll structures. Since actual tolls were often below the maxima specified in the charters (as the canals maximized their revenues), there was wide scope for varying the relative charges on different types of goods. (Unfortunately there do not appear to be any studies of the extent to which actual charges varied from the statutory ones.) Although tolls were supposed to be uniform and proportional to mileage, rebates offered a way around such rules. There were many other practices by canals that were regarded as abusive. In particular, canals would often gain control of all warehouses in their vicinity. Complaints about canal pricing, both as to the level of fees and to the extent of discrimination, were among the major reasons for the interest in development of railways (Jackman, 1916). Many of the complaints were not about canal operators, but about canal boat operators, who were generally not regulated (except for sporadic price limitation moves), and engaged in their own forms of price discrimination and other widely disliked pricing practices.

The Duke of Bridgewater's Canal was a special case. Its initial phase was intended to connect the Duke's coal mines at Worsley with the coal users in Manchester. It thus represented the ultimate in vertical integration, with the goods to be transported and all transport facilities controlled by the Duke (although there was provision for independent carriers). This canal did provide carriage for all goods throughout its commercial operation. At the same time, for many years it did encourage independent carriers, even though there were proposals to squeeze them out. There were many reasons for this encouragement of the carriers, a major one the perception, expressed in the words of the main manager in 1840 that "... no company can carry as economically as an individual" (Mather 1970, p.104). Thus the benefits of structural separation for the business of canal operation itself was recognized by the managers. But the tolls on the Duke of Bridgewater's Canal did depend all along on the nature of the cargo. Further, as competition with railways intensified in the late $1840 \mathrm{~s}$, the independent carriers were turned into commissioned agents of the Canal (Mather 1970, pp.199-200).

While canal operators were trying to squeeze carriers (who were trying to squeeze merchants, in ways similar to those described below for turnpikes), carriers often attempted to evade tolls. They bribed toll-collectors, misrepresented what the cargo was, or how much there was of it, and in some cases even hid cargo with high toll charges under commodities such as sand for which the fees were low. The countermeasures, just as they are today, and would likely be in the future with electronic communications, were based on both technology and law. Measurements were taken (in many cases there were books available to canal operators, listing canal boats, and the weight of cargo aboard as a function of how deeply in the water they lay), and there were punitive penalties for evasion. For fuller discussion of this phenomenon in England and the United States, see, for example, Gray (1989), Hadfield (1966), and Hadfield (1968).

\footnotetext{
${ }^{10}$ However, as is noted in Duckham (1983), for example, there were instances of canals experimenting with provision of direct carriage before that time. The Duke of Bridgewater's canal is an example.
} 


\section{$4 \quad$ Turnpikes and modern road transport}

British turnpikes were a controversial response to a serious problem. Traditionally, the King's Highway was open to all. The problem was how to keep it in good condition. As commerce grew, the need to maintain roads became acute. At first, in Elizabethan times, laws were enacted compelling all able-bodied commoner males to devote several days a year to labor on the highways. (See Albert, 1972, Pawson, 1977, and Webb and Webb, 1913 for references for the background information as well as other items below that are not attributed otherwise.) The inequitable distribution of the burden this imposed and the lack of effective control mechanisms by the central government led to many complaints. As a result, in 1663, the first turnpike was authorized. A local group was authorized to create a turnpike trust that would borrow money to improve a section of a road, and then collect tolls from travelers for passage over that section of the road. This venture was set up (as were all subsequent turnpikes) as an ostensibly non-profit trust. (There were opportunities for profits there, for example in payment of above-market fees and other abuses, but those were illicit, and in any case were not the high profits that other, more private, enterprises, such as lighthouses and canals, offered.) The reason for the non-profit nature of turnpikes was presumably to allay concerns about a violation of the ancient principle that the King's Highway was open to all. Still, this turnpike was very controversial (as were many later ones). Apparently largely for that reason, it took until 1695 before the next turnpike was set up (Albert, 1979).

In the early 18th century, the turnpike movement took off in earnest. Although there were frequent protests (sometimes violent, as in the burning of the toll gates around Bristol in 1727 and 1735), by mid-1830s there were over 20,000 miles of turnpikes in England. As stated in Pawson (1977, p.202),

The schedule of tolls chargeable by each trust was laid down in its Act. These varied considerably from trust to trust, ... The schedule itself was designed to cover all those categories of traffic which were considered to be a charge on road repair, differentiating to a certain extent on grounds of size and ability to pay. Each schedule was qualified by a list of exemptions and qualifications ...

Tolls were usually doubled on Sundays for ordinary commercial traffic, but were eliminated for travel to or from church. They also "were never levied on foot passengers, and were thus unfelt by the labouring poor" (Webb and Webb, 1913, p.124). There were also options in many cases for a flat fee for annual access. Still, there were countless controversies about the toll, "the collection of which led to endless evasions, inequalities and favouritisms of all kinds, arbitrary exactions, and systematic petty embezzlements" (Webb and Webb, 1913, p.136). As with canals, there do not appear to be any studies on how the widely varying toll schedules were determined.

Road transport presents an interesting contrast with canals. Road tolls formed a much smaller fraction of road carriers' costs than they did for canal carriers. It appears that in early 19th century Britain, tolls were 10-15\% of carrier costs (Gerhold, 1993, p.129). On the other hand, feed for horses was more than half of the costs. Thus variable costs were very high, which lessened incentives to price discriminate. Also, because the wagon, the unit of transport, was not all that expensive, shippers could avoid the most extreme cases of differential pricing by operating their own transport systems. Yet price discrimination was rife. Chapter 7 of Gerhold (1993) makes for fascinating reading on this subject. As it notes, the most important factor was "the principle of charging what the traffic would bear." There were variations by type of goods, and of course by locality (reflecting competitiveness of different markets), but "the main distinction was between gents' and 
trade price", and "gents' price could be anything from a seventh to a half above trade price" (Gerhold, 1993, p.153). Some of this differential reflected different costs, and often it was the result of explicit collusion. Still, this differential existed even in competitive situations. This provides yet another example of the fact that price discrimination can be consistent with vigorous competition.

So far I have been producing examples of the extensive practice of differential pricing on turnpikes and other transport systems. But what did it accomplish? Perhaps it was just a way to transfer money from users to owners, or else it might have been the result of some mistaken dogma. In most cases we have little solid evidence to decide. But there are a few examples that demonstrate the utility of this practice. For river navigation, the Beverley Beck Navigation, cited earlier, showed what appears to have been a beneficial impact from a more discriminatory toll structure. For turnpikes, we have the interesting recent studies of Bogart (2003) and Bogart (2004). They show that the introduction of turnpikes did lead to a substantial increase in spending on roads. (That is, the turnpike trusts, the non-profit entities improving and maintaining the roads, and collecting the tolls, spent considerably more on the roads than the parishes did on their own, in response to their legal obligation to maintain the King's Highway.) More interestingly, Bogart (2004) demonstrates that "land carriage rates fell by approximately $11-16 \%$ after turnpike trusts were adopted." Thus even though the free highway was replaced by a toll road with high charges imposed on carriers, the increased efficiency of transport on the turnpike led to end users paying less than before. At the same time they benefited from faster and more reliable service. Thus it seems fair to conclude that turnpikes were a positive contribution to society.

Yet another interesting observation in Gerhold (1993) is that transport charges did not vary much with season, even though underlying carrier costs (especially horse feed) were extremely variable. ${ }^{11}$ Thus one could say that customers in the summer months were subsidizing those sending goods in winter. This tendency for prices to vary much less than conventional economic profit maximization would suggest has been a puzzle to economists for a long time. It appears to be a response to the behavioral economics concerns that are discussed in Odlyzko (2003d), and which limit the spread of price discrimination.

The finances of the current road transport systems are hard to disentangle. There are a variety of user fees (registration, fuel taxes) as well as general tax revenues used. It is hard to tell just how much price discrimination is being practiced, but it is extensive (for example, in different charges for freight, as well as in higher profit rates on expensive cars). There are two important factors to bear in mind. One is that most of the costs are born by the end users directly (through purchases of cars, paying for insurance, gas, etc.). The other one is that road tolls are coming back as a result of growing congestion and improved technology. Unlike telecommunications, where technology is increasing capacity of fiber, coax, and radio transmissions, building new roads is increasingly difficult, and making existing ones carry more traffic can only be done to a limited extent. At the same time, electronic means for monitoring traffic and collecting tolls are improving, and we see central business districts in Norway, Singapore, and London imposing tolls. Most of these systems do raise privacy issues, too, since they are centralized ones with information about users, or at least cars. Still, there is a strong tendency to introduce ever more detailed

\footnotetext{
${ }^{11}$ For more extensive data on this, including statistics showing the narrowing of summer and winter fees with time, see Bogart (2003) and Bogart (2004). Carriers protected themselves from the wild swings in prices by stockpiling horse feed, but that basically meant they were absorbing the variations.
} 
monitoring of traffic, often with the explicit goal of charging users according to their level of activity (whether by governments or by insurance companies).

\section{$5 \quad$ Railroads}

Railroads were the dominant industry of the 19th century. Their similarities and contrasts with the Internet and the resulting implications for the economy as a whole make for interesting future research. Particularly striking are the results about privacy and price discrimination, summarized Odlyzko (2003d). In this section I present just some brief remarks on this topic.

Early railroad charters, in both England and the U.S., were modeled after canal and turnpike charters, and almost uniformly envisaged that railroad companies would not be carriers themselves. Instead, they were expected to offer their facilities for use by carriers that would carry goods and passengers in their own wagons over the rails. Still, these charters specified tolls that varied greatly depending on the nature of the cargo. (Since these were tolls for use of the rails, handling costs were not an issue, as those were covered by carrier charges. Any costs to the railway, such as wear and tear on the rails, were due to the weight of the cargo, independent of what it was.) For example, the very first parliamentary act for a railway was enacted in 1801. (Previous railways had been on private property, but in this case, as in subsequent ones, promoters were asking for the right of eminent domain to acquire the necessary land.) Between the endpoints of the railway, "chalk, lime and other manures were charged at the rate of three-pence per ton per mile; coals, corn, potatoes, iron and other metals, fourpence; and all goods not specified, sixpence" (Clifford, 1885, p.45). Thus there was no end-to-end principle, no open architecture, and no privacy for the goods that were carried. ${ }^{12}$

Although some railroads did operate with other companies' equipment on their rails for decades (and modern ones do so extensively), there was a relatively quick shift in the 1830 s and 1840 s towards railroads being exclusive carriers. There were technical reasons promoting such a shift (safety was jeopardized with multiple operators and primitive technology), but there is evidence that desire for greater control over pricing by railroads was also a major consideration (Odlyzko, 2003d). Once railroads became carriers, they could engage in much more extensive price discrimination than allowed by the toll

\footnotetext{
${ }^{12}$ An interesting observation is that, just as today, the government was trying to leave as much choice of technology as possible to the market (Clifford, 1885, p.54):

Parliament wisely refrained from binding the first railway projectors to adopt any specified form of rail. Whether a plank of wood or an iron plate should be used; whether the rail should be laid on stone or on wooden sleepers, should be flanged or smooth, should be flush with the ground, or sunk, or project above the ground, whether the wheels should be cogged or toothed, fitting into the rail as they revolved, to prevent skidding, or should offer a plain surface, guided by the grooved rail: these were questions with which Parliament did not meddle. Each of these plans, however, had its advocates, and was in turn adopted.

On the other hand, pricing, and especially the extent of price discrimination, were of intense interest to Parliament, and stringent limits were imposed in charters. (A relevant observation, in view of the claims that are being made today that carriers need to have absolute control over networks, or they won't invest in broadband, is that there did not seem to be any shortage of investment in canal navigation projects, canals, turnpikes, or railroads.) These limitations on price discrimination, primarily through detailed toll schedules, were pretty effective with canals and turnpikes, but not with railroads.
} 
structure in their charters. And, propelled by the economics of their industry, with high fixed costs, railroads did engage in massive price discrimination, including personal discrimination. The result was massive political movements leading to government regulation (Odlyzko, 2003d).

The full story of pricing policies of 19th century railroads is too vast to tell here. I will illustrate it with just one example, that of the "small freight wars" of 1840-1872 in Britain. (A much more detailed description is available in Kostal, 1994, Chapter 5.) Railroads had high rates for small packages, and low rates for large ones. This opened up a very profitable business for independent parcel-handlers. Purely for purposes of illustration, suppose that there were only two types of packages, of 50 pounds and 1,000 pounds, and a railroad had decided that the profit-maximizing price schedule was to charge $\$ 1$ for a 50 pound package, and $\$ 10$ for a 1,000 pound one. An outside agent could ruin this practice by practicing arbitrage, offering to convey 50 pound packages for $\$ 0.75$ each, and accomplishing this by assembling them into 1,000 pound ones, which it would then pay the railroad $\$ 10$ to convey (or $\$ 0.50$ per 50 pound package). That was basically what was happening in Britain in the 19th century. Railroads set out to fight this practice, by refusing to accept such combined packages from independent parcel-handlers, or by charging these shippers punitive rates. The parcel-handlers kept going to courts, which continued ruling in their favor and against the railroads. Still, railroads kept interfering with these carriers by making trivial modifications to their tariffs, just enough to be able to claim they were not doing what had been ruled illegal in the last lawsuit they had lost. (Those familiar with the UNE-P facilities sharing fights over the last few years in telecommunications may recognize some similarities.)

The point of the example above is that railroads could not resist the temptation to price discriminate even when it was plainly illegal to do so. Moreover, to do so, they had to have knowledge of the nature of the cargo they were carrying.

Eventually, railroad price discrimination led to a revolt, and government curbs on railroad pricing practices. The main complaint was usually less about the level of prices (which were typically far below the maximal levels envisaged in the charters), and more about inequities of differential pricing (Odlyzko, 2003d).

Government regulation, imposed at the end of the 19th century, did lead to stability for the railroad industry and prices that the public could be persuaded were largely fair. (It did not eliminate differential pricing for goods, though. The incentive for price discrimination was too strong, and charges continued to depend on the cargo.) However, regulation did strangle innovation in the industry, and resulted in gross inefficiencies. With time, the arguments that the costs of regulation were too high gained ground. In the U.S., railroads were deregulated by the 1980 Staggers Act. As a result, between 1984 and 2001, "inflation-adjusted rail rates fell 45\%" (St. Pierre, 2001). However, there are still complaints about both service quality and the degree of price discrimination. It is estimated "that captive shippers commonly pay rates $20 \%$ higher than shippers with competitive alternatives" (St. Pierre). The federal Surface Transportation Board can intervene in extreme cases of gouging, but the general perception is that competition from alternative modes of transportation is sufficient in most cases to provide a workable transportation system. It is a system, though, where prices depend on the nature of the cargo as well as local competitive conditions. 


\section{Telecommunications: A few observations}

The power of price discrimination was well understood already in ancient times, even if the economic concept was not defined. As the many historical vignettes presented before show, differential pricing was frequently allowed, but only to a controlled degree. The main concern in the early days was about general fairness and about service providers leveraging their control of a key facility into control over other businesses. Personal (first degree) discrimination was particularly hated, and preference was given to general rules applying to broad classes (such as student or senior citizen discounts today). Very often bounds on charges were imposed to limit price discrimination. But decision makers recognized the value of differential pricing, and were careful in limiting it. Even common carriers have traditionally been allowed some degree of differential pricing. To cite just one example, a British court decision of 1869 (Kostal, 1994, p.191) declared that

"At common law, a person holding himself out as a common carrier of goods was not under any obligation to treat all customers equally. ... All that the law required was that he should not charge any more than was reasonable."

The historical precedents presented here, together with basic economic arguments, help to at least partially explain the puzzling behavior of the telecommunications industry, as well as of the networking research community. They have devoted inordinate efforts to technologies such as ATM and QoS, even though there was abundant evidence these were not going to succeed. One can go further and say that essentially all the major networking initiatives of the last decade, such as ATM, QoS, RSVP, multicasting, congestion pricing, active networks, and $3 \mathrm{G}$, have turned out to have disappointed their proponents. Furthermore, they all disappointed not because the technical solutions that were developed were inadequate, but because they were not generally what users wanted. The misguided development of these technologies took place because researchers and developers refused to take a realistic look at how networks were used, and how they were likely to evolve. This behavior, though, appears to have been motivated largely by the message they kept hearing constantly from business people that differentiated services were a must. The basic motive for this message appears to have come from the incentive to price discriminate. The historical evidence shows how important a factor that has been in the past, especially in transportation, and so this push is understandable. Going forward, the incentives and the means to price discriminate will be increasing. This will lead to continued and even intensifying threats to the architecture of the Internet, especially the end-to-end principle, and to current business models.

Historically, telecommunications has in many ways behaved like transportation, with a constant tension between the incentives to price discriminate, and popular dislike of the practice. But the general trend in communications has been towards simpler pricing and decreasing price discrimination. This is described in detail in Odlyzko (2000b) and Odlyzko (2001b). There was one notable counterexample, though. The telephone started out with flat rates almost everywhere. The phone companies (private as well as government ones) then fought a worldwide battle, spanning several decades, to switch to metered billing. They succeeded almost everywhere, as is detailed in Odlyzko (2000b) and Odlyzko (2001b). They were supported by a remarkable consensus of experts. And indeed, the case for metering phone calls in those days was overwhelming, since there was a high marginal cost associated to each call, as action by an operator was required. The major exception to the switch to metered rates was the United States, where, aside from a few places such as Chicago and New York City, flat rates were preserved for residential local 
calling. This appears to have been the result of the competition between the Bell System and the independent phone companies. The need to cater to customer preferences meant that expert opinion did not prevail, and metered rates were not forced on everyone.

Although flat rates were regarded as damaging, they did not harm the U.S. telephone industry in the long run, as a comparison with other countries shows Odlyzko (2000b) and Odlyzko (2001b). U.S. phone industry revenues have traditionally been higher, as fractions of GDP, than those of most other countries, and the industry was dynamic and profitable. Moreover, flat rates for local calling played a key role in the rise of the Internet, by promoting much faster spread of this technology in the U.S. than in other countries. (This, as well as the FCC decisions about keeping Internet calls free from access charges, should surely be added to Scott Brandner's list of "the 10 key choices that were critical to the Net's success", Gillmor, 2002.)

Today, as was already noted in the Introduction, we are seeing the spread of flat rates to long distance telephony and even wireless. Yet although telephony is evolving towards simpler pricing, it did start out with a high degree of price discrimination and elaborate pricing. (That was also true of other systems. For example, postal services started out with distance-sensitive tariffs. Later, after switching to what are now known as "postal rates", independent of distance, they still were introducing services motivated by the incentives to price discriminate, such as postcards. Moreover, although there is a version of the end-toend principle and open architecture in postal systems, with first class mail generally protected from intrusion by postal employees, book rates involve potential inspections. There are also stringent restrictions on competition, and in the U.S. at least, post office boxes, although owned by residents, can only be used for mail.) As is detailed in Odlyzko (2000b) and Odlyzko (2001b), the earliest phone rates were twice as high for business as for residential users. (This disparity in charges for basic monthly fees persists in the U.S. to this day.) Later, high long distance rates were used to subsidize basic telephone service and local calling. Evening and weekend discounts were introduced as well (although they are now disappearing.) There were constant attempts to limit what customers could do, as in the Carterphone case in the 1960s where the Bell System attempted to control what could be interfaced with the phone network, and even in attempts to prevent customers from placing covers on their telephone directories. Hence it is possible to reconcile the view that pricing tends to get simpler and price discrimination decreases with advocacy of complicated pricing and extensive price discrimination for broadband access today. The argument then is that such measures are necessary to develop a new technology, even if eventually they might need to be phased out.

While there is a trend towards simpler pricing in telecommunications, and especially towards flat rates, there are also attempts to increase price discrimination. As an example, while wireline long distance voice rates are in general dropping, most carriers' basic plan rates are increasing, catching those who make few calls, or are ignorant or just procrastinate. There is also growth in other forms of first degree (personal) price discrimination, with wireless carriers, in particular, negotiating with individual customers.

Interestingly enough, even though the wireless industry is congratulating itself for avoiding the open architecture of the Internet, it has been remarkably poor at price discriminating. It has done some (and in particular has managed to charge for each handset). But it has failed to exploit other opportunities. It has fallen for the mirage of mobile Internet access, and has neglected the opportunities in providing differentiated voice services as well as toll-free wireless calling (Odlyzko, 2001a, Odlyzko, 2001c, and 
Odlyzko, 2003c). Such services provide promising opportunities for drawing more revenues from business users that are not being exploited.

For a more detailed discussion of the current state of the telecom industry see Odlyzko (2003b) and Odlyzko (2003c). Here I just reiterate a few key points, with some additional recent data. Total telecommunications service revenues in the U.S. (and all statistics in this section will be for U.S. alone) are around $\$ 300$ billion to $\$ 350$ billion per year. Most of that is voice, with wireless accounting for around $\$ 80$ billion. Although Internet backbone traffic volumes are much higher (by a factor of more than two at the end of 2003) than long distance voice volumes, Internet revenues are only about $\$ 35$ billion, with about $\$ 15$ billion coming from dedicated access, and $\$ 10$ billion each from dial access and residential broadband access. ${ }^{13}$

Especially important is the migration of costs on the Internet to the edges. Of the $\$ 35$ billion in annual Internet revenues, even the $\$ 15$ billion for dedicated access would shrink to $\$ 2$ billion if all the traffic coming in were aggregated into large pipes (Odlyzko, 2003b and Odlyzko, 2003c). (See also Newman, 2003 for costs of broadband access, and how little it costs for the basic network infrastructure, and Berman, 2003 for an example of the purchase of a cable that could in principle carry all the transatlantic traffic at a distressed sale price of $\$ 18$ million.) The core of the Internet, although of huge capacity, is not expensive to run. Technology has outrun demand, and the entire U.S. Internet backbone traffic could in principle be carried on a single fiber strand (Odlyzko, 2003b).

The fiber glut is a major contributor to this reduction of the core of the network to a low-cost commodity. However, as is discussed in Odlyzko (2003b) and Odlyzko (2003c), it is far from being the only reason. Technology had been reducing costs in the core far faster than at the edges even in the pre-Internet days. Even if one had to build a totally new fiber network from scratch, it would not be very expensive. Hence, aside from the incentive to price discriminate, the logical and economically efficient outcome is to run core networks as commodity providers of a uniformly high quality service. Given the degree of competition on major long distance routes and the lack of a player that might have a chance to monopolize fiber supplies, it appears overwhelmingly likely that core transport will continue to evolve towards a commodity. It will likely be profitable eventually for one or two players, after some consolidation, but it is unlikely to be a very large business.

On the other hand, historical precedents strongly suggest that total telecommunications spending should resume growing again, even when measured as a fraction of the economy Odlyzko (2000b). Most of that spending is likely to continue to be at the edges of the network. It may also increasingly be in forms that do not produce carrier revenues, as we move to customer-owned networks. (Signs of that are the fiber strands or wavelengths that large enterprises are increasingly purchasing to reach local exchange points, as well as the WiFi and other home networking setups that residential users are buying.) There may be more heterogeneity even in local access, with DSL, cable, and broadband all available to most users.

What we appear to be moving towards is a heterogeneous mixture of networks, unified through the Internet Protocol. Voice will be just one of many services delivered through a

\footnotetext{
${ }^{13}$ To be fair, it should be mentioned that private line and Frame Relay services, which provide intraenterprise connectivity, bring in revenues of about $\$ 30$ billion per year to the carriers. Those services are used primarily to carry IP traffic, so they are really part of the Internet, and serve to boost the Internet revenue figure to about $\$ 65$ billion per year.
} 
broadband link. The resulting system will likely resemble what Ted Stout calls the multimodal transportation system, with many technologies and specialized service providers available, and customers selecting the best one for their needs, often through intermediaries. (And indeed, we are beginning to see the emergence of such intermediaries in telecom; see Drogseth, 2003.) In such an environment, there will be a variety of players, and there will be price discrimination, but not through a single giant monolithic carrier, but through many competing enterprises.

If a multi-modal telecommunications industry does arise, that might limit the development of restrictive network architectures. There might also be some government action to assure interconnection.

Even if governments take a hands-off attitude, or promote closed architectures, there are other restraining influences. One comes from the fact that content is not king (Odlyzko, 2001a). Much of the inspiration for network designs has traditionally come from the myth that content (in the sense of material prepared by professionals for wide distribution, such as movies, or professional sports team performances) is where the money is. (Just consider the asymmetric bandwidth of cable modem and DSL residential broadband links.) But in fact there is far more money in providing basic connectivity. That is what people have always valued far more, and have been prepared to pay more for. While content delivery does lend itself to a closed network, connectivity does not. Open networks are likely to win because they can attract more revenues from users.

Closely related to the false myth that content is king is the preoccupation with real-time streaming multimedia transmission. That is what the networking industry has been aiming at for decades. Yet simple projections (as well as evidence of actual usage) show that file transfers are likely to dominate, Odlyzko (2000a) and St. Arnaud (1997). Furthermore, such file transfers are likely to be faster than real time, with the speed of the transfer providing a key quality differentiator. (In fact, the transition to dominance of faster than real time transmission of multimedia traffic has already occurred, even though the industry appears to be unaware of it or its significance. While MP3 file downloads using various P2P services are a huge factor on practically all networks, streaming traffic is tiny.) What this says, in effect, is that the networking industry is trying to do differential pricing in the wrong way, along the wrong dimension. Eventually they will learn the error of their ways, but it might be a long time until they do.

There are some other factors that argue for a comparatively open network. The increasing heterogeneity of the telecommunications network (as well as its increasing importance) will mean that users will be able to mitigate restrictive practices by bypassing service providers, as large enterprises are beginning to do by buying their own fiber. This bypass strategy will be facilitated by the general migration of costs and complexity to the edges. The rapid advances in fixed wireless threaten to make fiber-to-the-home unnecessary (Odlyzko, 2003c), and also to destabilize what might have developed into a cozy duopoly of DSL and cable modem providers. It will not be necessary for fixed wireless to grab the lion's share of the Internet access market. It may suffice if it has a small share, but is available as a viable alternative to DSL and cable modems.

A key distinction between the Internet and the transportation systems discussed earlier is that in transport, most of the costs were associated with the core of the network. On the Internet, on the other hand, the complexity, costs, and therefore revenue opportunities are largely at the edges. It is hard in such a situation to design a network architecture that will provide necessary controls for carriers. Furthermore (and this is very important in view of 
the discussion below about behavioral economic constraints), transportation charges tended to be levied relatively infrequently, on the carriers, and therefore users did not have to interact with them directly.

Yet another distinction is that in transportation, the nature and value of goods does not change very rapidly. In the new economy with extensive information goods, though, that is not the case.

Perhaps the most potent limitation on the proposed new architectures for the Internet, and the associated discriminatory practices, is posed by a range of factors deriving ultimately from behavioral economics. People react extremely negatively to price discrimination. They also dislike the bother of fine-grained pricing, and are willing to pay extra for simple prices, especially flat-rate ones. Furthermore (and this is specific to telecommunications and other information goods industries, and does not apply to transportation), technology is rapidly increasing available bandwidth, so the primary imperative for service providers is to persuade their customers to increase their usage. (The suggestion in Odlyzko, 2003c that telecom service providers buy out music studios and offer recorded music for free with their broadband connections was only slightly tonguein-cheek. The reviled peer-to-peer traffic is a major stimulant of the demand for broadband.) Constraining architectures and pricing structures work against increased usage. ${ }^{14}$ The general conclusion of Odlyzko (2000b) was that price discrimination and finegrained pricing are likely to prevail for goods and services that are expensive and bought infrequently. For purchases that are inexpensive and made often, simple pricing is likely to prevail. And we see these trends in the history of transportation. For example, as is outlined in Odlyzko (2003d), in the first half of the 19th century, railroads in England were limited in attempts to practice explicit price discrimination by law and lack of proper technology (such as the positive passenger identification that airlines rely on today). Hence they resorted to extreme forms of versioning, running third class passenger cars without roofs, and sometimes even without seats. These practices led to the famous 1844 law that forced the railroads to run the so-called "Parliamentary trains", something they did only under duress and with loud protests. This was in the early days of the industry, when railroad travel was rare and expensive. By the end of the 19th century, the overwhelming majority of passengers traveled in 3rd class cars, which by that time were much more comfortable. ${ }^{15}$ Now the Internet already pervades society, and will be even more ubiquitous in the future, used round the clock in a variety of applications. Simplicity is likely to be key to acceptance. We see this phenomenon in operation today. Although hotels, golf courses, and other service providers are rushing to imitate airline yield management systems, many are discovering that this is not necessarily the way to riches. For example, Amtrak, after extensive experimentation with complicated pricing, has decided to pull back to the traditional approaches of simple and stable fares Machalaba (2003). Hence telecom service providers are likely to discover that the elaborate architectures they are dreaming of will work against their interests.

\footnotetext{
${ }^{14}$ For more details, see Fishburn, Odlyzko, and Siders (1997), Odlyzko (2000b), and Odlyzko (2001b) and (for a short version with pointers to the literature) Odlyzko (2003a).

${ }^{15}$ And even then, just as today, operators had great difficulty figuring out how their business was evolving. As was noted by an observer in 1885, at that time "[r]ailway managers had not yet discovered that third class traffic was their main stay," (Clifford, 1885, p.100).
} 


\section{$7 \quad$ Conclusions}

The historical record of early transportation industries demonstrates that price discrimination was integral to their operations, was regarded as very important by operators as well as government policy makers, and generally tended to intensify with time. Tolls almost always depended on the nature of the cargo, and therefore carriers had the right to inspect the cargo in detail. On the other hand, personal (first degree) discrimination was invariably forbidden.

This historical record helps explain the push in the telecommunications industry for new network architectures that would provide service providers greater control of what customers do, and would deviate from the "stupid network" model of the Internet. However, there are substantial differences between the Internet and the old transportation systems, and even today's transport differs in important respects from that of centuries ago. The Internet is special, in its migration of costs and capabilities to the edges, in its primary value being in connectivity and low transaction latency, and in its pervasiveness and frequency of use. Hence the historical precedents from transportation discussed in this paper may not apply to the future of the Internet.

\section{Appendix: Coase's lighthouse myth}

Ronald Coase's paper (Coase, 1974), "The lighthouse in economics," has had tremendous impact on economic thought. It claimed to show that lighthouses, which had often been cited as prototypical examples of public goods that only governments can provide, had in the past been provided in England by private enterprise. This suggested to many that the role of government could be shrunk, as many of its functions could be provided by profitmaking entities acting in their own interests, hopefully with some gain in economic efficiency. The Coase paper continues to be cited frequently as a breakthrough result. Unfortunately, many conclusions drawn from Coase's paper are unjustified. As an example, a recent commentary, Warsh (2002), claimed that Coase had shown that "[i]nstead of the government-sanctioned 'light dues' charged by Trinity House, developers persuaded ship-owners to sign up in advance for voluntary tolls." This claim from Warsh (2002) is incorrect, as are many of the conclusions commonly drawn from Coase's paper. In defense of Coase, it has to be said that in his paper he never referred to "voluntary tolls" and did not make the extreme claims some of his followers have put forth. However, Coase's paper uses very ambiguous language to describe the English lighthouse system, and is deeply flawed. Amazingly enough, even though any serious economic historian should have been able to see instantly the faults in the paper, it continued to be accepted uncritically for a quarter of a century. The first debunking appears to have been by Richard Epstein in 1999, Epstein (1999), and a more thorough one was presented by Daniel Davis in 2002, Davis (2002). (For an earlier, more general criticism of the Coase paper, see Varian (1994) which has an excellent short summary of the key issues related to public goods.) These contributions are not very well known even today, though.

For an easily accessible history of British lighthouses, see Trethewey (2004), from which much of the information below is taken. What are the basic problems with Coase's paper? It is true that lighthouses were frequently constructed, operated, and owned (with rights of inheritance and sale) by private individuals. However, they were only exceedingly 
seldom the result of freely negotiated private contracts. They were usually the result of a grant (called a "patent" in those days) from the king, sometimes for a few decades, sometimes in perpetuity. This grant entitled the holder to construct a lighthouse in a particular location and to collect compulsory fees from all ships entering nearby harbors. The fees were set by the terms of the grant, and were often collected by government customs agents. Moreover, lighthouse owners did not just have the right to collect the dues, they had the obligation to provide lighthouse services. We read, for example, of King James I in 1623 reducing in half the compulsory levy for a lighthouse that was poorly maintained (Trethewey, 2004). There were instances of grants that did not entail the right to collect compulsory lighthouse duties, but those (as anyone before Coase would have predicted) were generally not successful.

Some of the privately owned lighthouses were extremely lucrative. When they were taken over by the government in the 1830 s and early 1840 s, owners were compensated. The record payment was to the owners of the Skerries Rock lighthouse, who received approximately $\$ 2.2$ million. (In comparison, the Louisiana Purchase cost the U.S. \$15 million, and the acquisition of Alaska $\$ 7.2$ million.) Still, these private lighthouses were clearly agents of the government. They had the duty imposed by the government of providing services. They also had the power of compelling payment (at least for ships entering British harbors), even from ships that did not rely on them. Shipowners did not have the option of saying that since their ships would only sail in daylight and fair weather, they did not need lighthouses and did not have to pay. The lighthouse arrangement was similar to many that governments used to employ in order to compensate for the lack of information and control technologies. "Tax farming" and even sales of officer positions in armies were common in Europe well into the 19th century. Yet it seems that everybody agrees that these were public goods provided by governments. Thus Coase's lighthouse paper certainly fails to support the thesis that is ascribed to it in places such as Warsh (2002). A good overall evaluation of Coase's paper is in a phrase that Coase used to refer to the works of Mill, Sidgwick, Pigou, and Samuelson. It makes "statements about lighthouses which are misleading as to the facts, whose meaning, if thought about in a concrete fashion, is quite unclear, and which, to the extent that they imply a policy conclusion, are very likely wrong" Coase (1974, pp.169-182).

\section{$9 \quad$ References}

Albert, W. (1972) The Turnpike Road System in England, 1663-1840. Cambridge University Press: England.

Albert, W. (1979) "Popular Opposition to Turnpike Trusts in Early Eighteenth Century England," Journal of Transport History, 5: 57-68.

Berman, D. K. (2003) “Telecom Investors Envision Potential in Failed Networks," Wall Street Journal, August 14.

Bogart, D. (2003) "Institutional Innovation and Infrastructure Investment: An Evaluation of the Turnpike System in Eighteenth Century England," November 26 Draft. http://aris.ss.uci.edu/econ/paper/2003-04/Bogart-02.pdf. 
Bogart, D. (2004) "Turnpike Trusts and the Transportation Revolution in Eighteenth Century England," Draft, January 7. http://orion.oac.uci.edu/ d dbogart/transport_revolution_feb12_two.pdf

Brindley, J. (1766) The History of Inland Navigations, Particularly those of the Duke of Bridgewater, in Lancashire and Cheshire, and the Intended One Promoted by Earl Gower and Other Persons of Distinction in Staffordshire, ..., T. Lowndes: London.

Christensen, A. E. (1941) Dutch Trade to the Baltic about 1600: Studies in the Sound Toll Register and Dutch Shipping Records, E. Munksgaard: Copenhagen, and Martinus Nijhoff: The Hague.

Clifford, F. (1885) A History of Private Bill Legislation, Volume 1. Butterworths: London.

Coase, R. H. (1946) “The Marginal Cost Controversy,” Economica, New Series 13: 169182.

Coase, R. H. (1974) "The Lighthouse in Economics," Journal of Law and Economics, 17: 357-376. Reprinted in Coase, R. H. (1988) The Firm, the Market, and the Law. University of Chicago Press: Chicago.

Davis, D. (2002), "Shine Your Light on Me ...," December 23 blog entry. http://dsquareddigest.blogspot.com/2002_12_22_d-squareddigest_archive.html\#86435321.

de Vries, J. (1981) Barges and Capitalism: Passenger Transportation in the Dutch Economy, 1632-1839. HES Publishers: Utrecht.

Drogseth, D. (2003) "New providers manage bandwidth acquisition," Network World, October 6. http://www.nwfusion.com/newsletters/nsm/2003/1006nsm1.html.

Duckham, B. F. (1972) The Inland Waterways of East Yorkshire, 1700-1900. East Yorkshire Historical Society: Manchester.

Duckham, B. F. (1983) "Canals and River Navigation," in Aldcroft, D. H. and M. J. Freeman (eds.) Transport in the Industrial Revolution, 100-141. Manchester University Press: Manchester.

Epstein, R. A. (1999) "The Libertarian Quartet," Reason, January. http://reason.com/9901/bk.re.thelibertarian.shtml.

Fishburn, P. C., A. M. Odlyzko, and R. C. Siders (1997) "Fixed Fee Versus Unit Pricing for Information Goods: Competition, Equilibria, and Price Wars," First Monday, Volume 2, July. http://firstmonday.org/issues/issue2 7/odlyzko/index.html.

Gerhold, D. (1993) Road Transport Before the Railways: Russell's London Flying Waggons. Cambridge University Press: England. 
Gillmor, D. (2002) "10 Choices that were Critical to the Net's Success," The Mercury News, September. 8.

http://www.siliconvalley.com/mld/siliconvalley/business/columnists/4029770.htm.

Gray, R. D. (1989) The National Waterway: A History of the Chesapeake and Delaware Canal, 1769-1985. University of Illinois Press: Urbana.

Hadfield, C. (1966) British Canals: An Illustrated History, 2nd ed., 3rd printing. David \& Charles: Newton Abbot.

Hadfield, C. (1968) The Canal Age. David \& Charles: Newton Abbot.

Huang, R. (1964) The Grand Canal During the Ming Dynasty, 1368-1644, Ph.D. Thesis, University of Michigan.

Jackman, W. T. (1916) The Development of Transportation in Modern England. Cambridge University Press: England.

Kirkaldy, A. W. and A. D. Evans (1915) The History and Economics of Transport. Pitman \& Sons: London.

Kostal, R. W. (1994) Law and English Railway Capitalism, 1825-1875. Oxford University Press: Oxford.

Machalaba, D. (2003) "Amtrak Ttimetables to Feature Ticket Prices, Simpler Format," Wall Street Journal, August 6.

MacMahon, K. A. (1971) "Beverley and its Beck: Borough finance and a town navigation 1700-1835," Transport History, 4: 121-143.

Maczak, A. (1972) Miedzy Gdanskiem a Sundem: Studia nad Handlem Baltyckim od Polowy XVI to Polowy XVII Wieku, Panstwowe Wydawnictwo Naukowe: Warsaw.

Maistre, A. (1968) Le Canal des Deux Mers: Canal Royal du Languedoc 1666-1810, Edouard Privat, Toulouse.

Malet, H. (1977) Bridgewater: The Canal Duke, 1736-1803. Manchester University Press: Manchester.

Marvin, C. (1990) When Old Technologies Were New: Thinking About Electric Communication in the Late Nineteenth Century. Oxford University Press: Oxford.

Mather, F. C. (1970) After the Canal Duke: A Study of the Industrial Estates Administered by the Trustees of the Third Duke of Bridgewater in the Age of Railway Building 18251872. Oxford University Press: Oxford. 
Newman, S. (2003) "Broadband Access Platforms for the Mass Market: An Assessment," presented at 2003 Telecommunications Policy Research Conference. http://intel.si.umich.edu/tprc/papers/2003/254/BbandAccessPlatforms.pdf.

Odlyzko, A. M. (2000a) "The Internet and other networks: Utilization rates and their implications," Information Economics \& Policy, 12: 341-365. Presented at the 1998 Telecommunications Policy Research Conference. http://www.dtc.umn.edu/ odlyzko/doc/recent.html.

Odlyzko, A. M. (2000b) "The History of Communications and its Implications for the Internet," unpublished manuscript. http://www.dtc.umn.edu/ odlyzko/doc/recent.html.

Odlyzko, A. M. (2001a) "Content is Not King," First Monday, Volume 6, February. http://firstmonday.org/issues/issue6 2/odlyzko/.

Odlyzko, A. M. (2001b) "Internet Pricing and the History of Communications," Computer Networks, 36: 493-517. http://www.dtc.umn.edu/ odlyzko/doc/recent.html.

Odlyzko, A. M. (2001c) "Talk, Talk, Talk: So Who Needs Streaming Video on a Phone? The Killer App for 3G may turn out to be Surprise-voice Calls," Forbes, August 20. http://www.dtc.umn.edu/ odlyzko/doc/recent.html.

Odlyzko, A. M. (2003a) "The Case Against Micropayments," in Wright, R. N., (eds.), Financial Cryptography: 7th International Conference, FC 2003, Lecture Notes in $\begin{array}{llll}\text { Computer } \quad \text { Science } & \text { \#2742, } & \text { Springer, }\end{array}$ http://www.dtc.umn.edu/ odlyzko/doc/recent.html.

Odlyzko, A. M. (2003b) "Internet Traffic Growth: Sources and Implications," in Dingel, B. B., W. Weiershausen, A. K. Dutta, and K.-I. Sato, (eds.), Proc. SPIE, 5247: 1-15. http://www.dtc.umn.edu/ odlyzko/doc/recent.html.

Odlyzko, A. M. (2003c) "The many paradoxes of broadband," First Monday, Volume 8, September. http://firstmonday.org/issues/issue8_9/odlyzko/index.html.

Odlyzko, A. M. (2003d) "Privacy, Economics, and Price Discrimination on the Internet," in Sadeh, N., (eds.), ICEC2003: Fifth International Conference on Electronic Commerce, ACM Press, 355-366. http://www.dtc.umn.edu/ odlyzko/doc/recent.html.

Pawson, E. (1977) Transport and Economy: The Turnpike Roads of Eighteenth Century Britain. Academic Press: London.

Phillips, J. (1792) A General History of Inland Navigation, Foreign and Domestic; Containing a Complete Account of the Canals Already Executed in England, with Considerations .... I. and J. Taylor: London.

Priestley, J. (1967) Historical Account of the Navigable Rivers, Canals and Railways Throughout Great Britain, 2nd ed. Frank Cass \& Co.: London 
Prouty, R. (1957) The Transformation of the Board of Trade, 1830-1855: A Study of Administrative Reorganization in the Heyday of Laissez Faire. William Heinemann: London.

St. Pierre, N. (2001) "Railroads: Asleep at the Switch: Lousy Service is Driving Away Freight Customers," Business Week, April 2.

St. Arnaud, B. (1997) "The Future of the Internet is NOT Multimedia," Network World, November. http://www.canarie.ca/ bstarn/publications.html.

Thacker, F. S. (1968) The Thames Highway: Vol. I: General History. David \& Charles: Newton Abbot.

Trethewey, K. (2004) The Background to Lighthouse History in England, Ireland, Scotland and Wales. http://www.btinternet.com/ k.trethewey/genindex.html.

Varian, H. R. (1994) "Markets for Public Goods?" Critical Reviews, 4: 539-557. http://www.sims.berkeley.edu/ hal/public.pdf.

Warsh, D. (2002), economicprincipals.com column, September 29.

http://www.economicprincipals.com/issues/02.09.29.html.

Webb, S. and B. Webb (1913) English Local Government: The Story of the King's Highway. Longmans: London.

Whitford, N. E. (1906) History of the Canal System of the State of New York Together with Brief Histories of the Canals of the United States and Canada, Brandow. http://www.history.rochester.edu/canal/bib/whitford/1906/contents.html.

Wilke, J. R. and D. Clark (2004) "Microsoft is Facing More Telling E-mails in Minnesota Lawsuit," Wall Street Journal, March 17.

Willan, T. S. (1964) River Navigation in England. Frank Cass \& Co.: London.

Willan, T. S. (1965) The Early History of the Don Navigation. Manchester University Press: Manchester. 